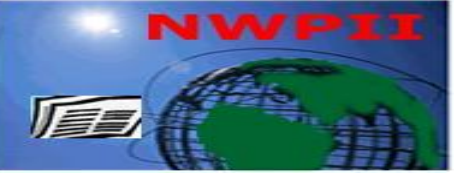

American Journal of Biomedical Sciences

ISSN: 1937-9080

nwpii.com/ajbms

\title{
Intratracheal Instillation of Surfactant Inhibits Lipopolysaccharide-induced Acute Respiratory Distress Syndrome in Rats
}

\author{
Neha Mittal and Sankar Nath Sanyal* \\ Department of Biophysics, Panjab University, Chandigarh-160014, India \\ *Corresponding Author: \\ Dr. S. N. Sanyal \\ Department of Biophysics \\ Panjab University \\ Chandigarh-160014 \\ India \\ Phone: +91-0172-2534122 \\ Email: $\quad$ sanyalpu@gmail.com \\ $\underline{\text { sanyal@pu.ac.in }}$
}

Received: 17 December 2009; | Revised: 8 February 2010; | Accepted: 23 February 2010

\begin{abstract}
To determine the possible contribution of apoptosis in the pathogenesis of ARDS, we investigated the role of exogenous surfactant in a rodent model of ARDS after intratracheal instillation of lipopolysaccharide. Adult male Sprague Dawley rats were divided into four groups: buffer controls; rats challenged with LPS (055:B5 E.coli); challenged with LPS and treated with porcine surfactant (P-SF); and challenged with LPS and treated with synthetic surfactant (S-SF). Parameters of lung injury and inflammation were assessed $72 \mathrm{~h}$ after treatment. We demonstrated that intratracheal administration of LPS could provoke significant lung injury, which was characterized by increase of MPO activity, wet/dry lung weight ratio, cytokine levels in bronchoalveolar lavage fluid (BALF), apoptosis of BALF cells and caspase-3 activity in lung tissue. Intratracheally delivered surfactant significantly reduced the parameters of LPS-induced inflammation: infiltration of inflammatory cells into lung tissue and BALF, pulmonary edema, lung myeloperoxidase activity, lipid peroxidation, caspase-3 activity, number of apoptotic BALF cells, lactate dehydrogenase level \& pro-inflammatory cytokines levels. Taken together, the present data demonstrate that exogenous surfactant systemically attenuates lipopolysaccharide-induced inflammation.
\end{abstract}

Keywords: ARDS; LPS; surfactant; caspase; cytokines; LDH; apoptosis; myeloperoxidase; edema.

\section{Introduction}

Pulmonary surfactant is a complex of highly bioactive phospholipids and proteins that cover the alveolar epithelial surface of the lungs [1].
Surfactant is synthesized in the alveolar type-II cells, stored in the lamellar bodies, and secreted to the alveolar space where it undergoes complex changes [2]. The composition of surfactant includes phospholipids $(85 \%)$ and main C 2010 by NWPII. All rights reserved. 
component is dipalmitoylphosphatidylcholine (DPPC). In addition, surfactant contains different apoproteins, neutral lipids and carbohydrates [3]. Pulmonary-surfactant dysfunction can lead to acute lung injury and is characterized by alveolar instability, floating and collapse. These abnormalities have been shown to occur in acute respiratory distress syndrome (ARDS) $[4,5]$ and infant respiratory distress syndrome (IRDS) [6]. It is now known that surfactant dysfunction plays a major role in the pathophysiology of ARDS [5, 7], and functional changes have been described not only in patients with established ARDS, but also in patients at risk [7-9]. The main biochemical abnormalities include an $80 \%$ fall in the total phospholipid content, decline in the fractional content of DPPC and phosphatidylglycerol and other fractions, and loss of apoproteins (90\% of surfactant protein SP-A and SP-B) [5, 6]. This loss of alveolar surfactant is due to several factors including intratracheal application of bacterial endotoxin which leads to an inflammatory reaction with pathologic characteristics, resembling an acute respiratory distress syndrome. The acute lung injury (ALI) represents a suitable experimental system to investigate the immunopathologic mechanisms of acute respiratory distress syndrome [10]. Exogenous surfactant replacement therapy has been successfully achieved in IRDS [6], but clinical trials in ARDS have had mixed results.

Lipopolysaccharide (LPS) is a major pathogenic factor in gram-negative sepsis, which is characterized by shock and multiorgan dysfunction. In response to systemic LPS exposure, proinflammatory cytokines such as tumor necrosis factor (TNF- $\alpha$ ), interleukin (IL)$1 \beta$, and interferon- $\gamma($ IFN- $\gamma)$ are produced by the host, which have been shown to either directly or indirectly mediate many of the hemodynamic and inflammatory changes, and organ damage in sepsis. Animal models of septic shock indicated that apoptosis, an active cellular process of cell death under genetic control, contributed to the primary organ damage [11].

The respiratory system is continuously exposed to low levels of LPS, which is ubiquitously present as a contaminant on airborne particles, including air pollution [12], organic dust [13], and cigarette smoke [14]. Exposure to high LPS levels is known to provoke acute lung inflammation, partly initiated via the early endogenous induction of IL$1 \beta$ and TNF- $\alpha$ in the lung. These cytokines are thought to contribute to the pathogenesis of acute inflammation by inducing the expression of endothelial leukocyte adhesion molecules and chemokines such as monocyte chemoattractant protein-1 (MCP-1) and macrophage inflammatory protein-2 (MIP-2). All these inflammatory mediators together play a crucial role in the orchestration of an inflammatory response consequently leading to recruitment of neutrophils into alveoli. Neutrophils play a prominent role in the host defense against pathogens, but are also considered to be responsible for pulmonary injury, manifested by increased lung vascular permeability, edema, and cell death [15]. The presence of neutrophils was suggested to induce apoptotic cell death in primary human bronchial epithelial cells [16]. Studies suggest that cytokines and chemokines do not only originate from the alveolar macrophages, but also from other cells such as epithelial cells [17]. Also in vitro studies indicated that LPS can directly trigger pulmonary cells to undergo apoptosis [18].

In view of the continuous exposure of the lungs to LPS, we studied whether local exposure to LPS in vivo results in inflammation of lungs and to see the efficacy of exogenous surfactant on LPS induced ARDS pathogenesis. To this end, rats were intratracheally challenged with LPS and treated with exogenous surfactant, and parameters of lung injury and inflammation were assessed $72 \mathrm{~h}$ after treatment.

\section{Material and methods}

\subsection{Animal modal}

Male rats of S.D. strain, weighing $150-200 \mathrm{~g}$ were taken from the Central Animal House of Panjab University for all the studies as described here. The animals were kept in polypropylene cages under hygienic conditions and supplied with pellet diet and drinking water ad libitum. Control group of animals were administered with $300 \mu \mathrm{l}$ of the buffer $(50 \mathrm{mM}$ Tris-HCl, pH-7.4, 150mM $\mathrm{NaCl}, 1 \mathrm{mM} \mathrm{NaN} \mathrm{N}_{3} \& 0.2 \mathrm{mM}$ PMSF). For LPS

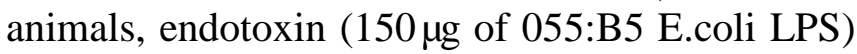


was suspended in $300 \mu 1$ of surfactant buffer. All rats were anesthetized with ketamine $(130 \mathrm{mg} / \mathrm{kg}$. i.p.), such that they remained unconscious throughout the entire instillation procedure and had no cough reflex upon intubation. A small incision was made on the ventral region of the neck and the trachea carefully exposed. Animals were then placed on a slight incline, intubated with a 26-gauge needle and either buffer or LPS instilled followed by 2-3 boluses of $1 \mathrm{ml}$ air to facilitate the distribution of the instilled fluid. Shortly thereafter, when normal spontaneous breathing was apparent, the neck incision was closed with silk sutures. To avoid any infection the betadine and neosporin powder were applied to the wound area. Two hours prior to killing, surfactant isolated from porcine $(500 \mu \mathrm{g}$ protein $/ 300 \mu \mathrm{l}$ ) or synthetic surfactant $(6.95 \mathrm{mg} / 300 \mu \mathrm{l})$ were intratracheally instilled in PSF and S-SF groups, respectively after LPS administration following the identical instillation procedure. The animals were sacrificed at 72 hours after buffer or LPS instillation [19]. All of the animal procedures as reported here had been carried out following the guidelines approved by the Panjab University Ethical Committee on the use of the experimental animals for biomedical research.

\subsection{Surfactant preparation}

Surfactant was isolated from porcine lung homogenate (P-SF) by sucrose density gradient method [20] and protein free synthetic surfactant (S-SF) was prepared with $13.9 \mathrm{mg} / \mathrm{ml}$ dipalmitoylphosphohatidyl choline (DPPC), $1.5 \mathrm{mg} / \mathrm{ml}$ hexadecanol and $1.0 \mathrm{mg} / \mathrm{ml}$ Tylaxopol [21].

\subsection{Bronchoalveolar lavage fluid (BALF) isolation}

At the end of each experiment, a bronchoalveolar lavage was performed using $5 \mathrm{ml}$ phosphate buffered saline (PBS, pH-7.4). The average fluid recovery was greater than $90 \%$. The recovered volume was centrifuged at $1000 \mathrm{rpm}$ for $10 \mathrm{~min}$ at $4^{0} \mathrm{C}$ and the supernatants were stored at $20^{\circ} \mathrm{C}$ until analysed. Furthermore, the cell pellet was redissolved in PBS and subsequently the number of total cells as well as the fraction of neutrophils were counted using a Neubayer's hemocytometer. Differential counts were performed on 200 cells stained with Wright Giemsa [22].

\subsection{Pulmonary edema formation}

Pulmonary edema was estimated by the wet/dry (W/D) lung weight ratio, a technique commonly used for assessment of experimental lung injury [23]. Briefly, after exposure to the desired experimental condition, animals were killed. One lobe of lung tissue from lower right lobe was cut and its wet weight was determined in an automatic electronic balance (Shimadzu, Japan). The lung tissue was then put in an oven at $90^{\mathrm{O}} \mathrm{C}$ for $48 \mathrm{hr}$ and weighed again to obtain its dry weight for calculation of wet-to-dry lung weight ratio.

\subsection{Determination of MPO activity}

Myeloperoxidase (MPO) was determined for the relative number of PMN sequestered in the lungs. Lung tissue samples (200mg) were homogenised in $1.8 \mathrm{ml}$ of $0.5 \%$ of hexadecyltrimethylammonium bromide in $50 \mathrm{mM}$ potassium phosphate buffer ( $\mathrm{pH}$ 6.0) with detergent in an ice bath. Samples were sonicated to disrupt the granules and solubilize them in the hexadecyltrimethylammonium bromide. Samples were then centrifuged at $8,000 \mathrm{rpm}$ for $10 \mathrm{~min}$ at $4^{0} \mathrm{C}$. Assay buffer comprised $750 \mu \mathrm{l}$ of $1.7 \mathrm{mM}$ $\mathrm{H}_{2} \mathrm{O}_{2}$ and $650 \mu \mathrm{l}$ of $2.5 \mathrm{mM}$ 4-aminoantipyrene with $2 \%$ phenol. An aliquot of $100 \mu 1$ of supernatant of each sample was mixed into $1.4 \mathrm{ml}$ of assay buffer at room temperature. Results are expressed as relative change in absorbance per minute at 460nm. One unit of MPO was defined as causing a change of 1.0 absorbance and the data were expressed as U/g lung tissue [24].

\subsection{Determination of MDA levels}

MDA levels in lung tissue were determined as an indicator of lipid peroxidation. Lung tissue was homogenised in $1.15 \% \mathrm{KCl}$ solution. An aliquot $(100 \mu 1)$ of the homogenate was added to a reaction mixture containing $200 \mu \mathrm{l}$ of $8.1 \%$ thiobarbituric acid and $700 \mu \mathrm{l}$ of distilled water. Samples were then boiled for $30 \mathrm{~min}$ at $100^{\circ} \mathrm{C}$ and centrifuged at $3,000 \mathrm{rpm}$ for $10 \mathrm{~min}$. The absorbance of the 
supernatant was measured spectrophotometrically at $532 \mathrm{~nm}[25]$.

\subsection{Cytokines measurement in BAL fluid}

The concentration of IL- $1 \beta$, TNF- $\alpha$, IFN $-\gamma$, MCP-I and MIP-2 in rats BAL fluid were measured by using a commercially available ELISA kit (Bender Med Systems, CA, USA and Ray Biotech Inc, Norcross, GA, USA). Optical density was read at $450 \mathrm{~nm}$ using a microplate reader MIOS mini (Merck, USA).

\subsection{Lactate dehydrogenase (LDH) assay}

Lactate dehydrogenase levels were assayed in BALF as a measure of lung injury using a cytotoxicity detection kit (Cayman Chemicals, Ann Arbor, MI, USA). LDH catalyses the reduction of $\mathrm{NAD}^{+}$to $\mathrm{NADH}$ and $\mathrm{H}^{+}$by oxidation of lactate to pyruvate. Diaphorase uses the newly formed NADH and $\mathrm{H}^{+}$to catalyse the reduction of a tetrazolium salt to highly colored formazan which absorbs strongly at 490-520nm. The amount of formazon produced is proportional to the amount of LDH released into the culture medium as a result of cytotoxicity. Optical density was read at $490 \mathrm{~nm}$ using a microplate reader MIOS mini (Merck, USA).

\subsection{Caspase activity analysis}

The activity of caspase- 1 and caspase- 3 were determined using a fluorimetric assay system. In brief, lung protein extracts were prepared by the homogenization of frozen lung tissues in a hypotonic buffer $(25 \mathrm{mM}$ Hepes, $\mathrm{pH} 7.5,5 \mathrm{mM}$ $\mathrm{MgCl}_{2}, 1 \mathrm{mM}$ phenylmethyl sulfonyl fluoride (PMSF), $1 \mathrm{mg} / \mathrm{ml}$ leupeptin and aprotinin). Homogenates were centrifuged $(15,000 \mathrm{rpm}, 10$ $\left.\min , 4^{0} \mathrm{C}\right)$, and the supernatants were used. $20 \mathrm{ug}$ of the extracted proteins were incubated with the fluorescent substrates YVAD-AMC (Ac-Tyr-ValAla-Asp-aminomethylcoumarin) for caspase-1 or DEVD-AMC (Ac-Asp-Gul-Val-Aspaminomethylcoumarin) for caspase-3. The fluorescence of cleaved substrates was determined using a spectrofluorimeter (Perkin Elmer LS55) at an excitation wavelength of $360 \mathrm{~nm}$ and an emission wavelength of $460 \mathrm{~nm}$. The caspase activity was expressed in picomoles per minute per milligram of protein [26].

\subsection{Protein estimation by Bradford method}

The method followed was based on the details given in the product description as provided by the manufacturer (Sigma, USA). To $50 \mu \mathrm{l}$ of tissue homogenate was added $1.5 \mathrm{ml}$ of Bradford reagent to each tube and vortexed gently for thorough mixing and incubated at room temp for $5 \mathrm{~min}$. Samples were then read for their absorbance at $595 \mathrm{~nm}$. Appropriate standards were also run along with the tests.

\subsection{Apoptosis by fluorescent dyes co-staining}

Acridine orange is a fluorescent agent, which can intercalate (slip in) between base pairs (bp) in the central stack of DNA helix and bind to the G$\mathrm{C}$ base pairs. This staining procedure was performed according to the details provided by Baker et al [27]. Briefly, the cells were suspended in PBS (pH 7.4, HiMedia, Mumbai, India) and were dual stained with acridine orange and ethidium bromide $(1 \mu \mathrm{g} / \mathrm{ml})$ in the same concentration for $5 \mathrm{~min}$ at $37^{\circ} \mathrm{C}$. Yellow and green fluorescence cells were examined under fluorescence microscope (x 400) (Axioscope, Zeiss, Germany). In Hoechst 33342-propidium iodide co-staining, Hoechst 33342 dye is used to stain DNA, because it is also a DNA intercalating dye and binds to A-T base pairs. Staining procedure was performed by the method of Yuan et al [28]. Briefly, to $10 \mu \mathrm{l}$ of the harvested cells, $5 \mu \mathrm{lof} 1 \mathrm{mg} / \mathrm{ml}$ propidium iodide (PI) and $5 \mu \mathrm{l}$ of $1 \mathrm{mg} / \mathrm{ml}$ Hoechst 33342 dye was added under dark conditions. Cell suspension was kept at room temp for $5 \mathrm{~min}$ and after this cell suspension was placed on a clean glass slide and examined under a fluorescence microscope for red and blue fluorescent cells. For quantification of the extent of apoptosis, a total of 100 cells from five different slides were observed and photographed at 40 fold magnification using a Zeiss Axioscope microscope (Carl Zeiss, Germany). Percentages of apoptotic cells were calculated for the individual animal.

\subsection{Statistical analysis:}

Statistical analysis was performed using SPSS version 10.0 software. One way analysis of variance (ANOVA) was done to compare the (C) 2010 by NWPII. All rights reserved. 
means between the different treatments using Post-Hoc comparison by Least Significant Difference (LSD) method. A value of $p<0.05$ was considered significant in the present study. All data were expressed as Mean \pm SD of five animals for each group.

Figure 1 (a)

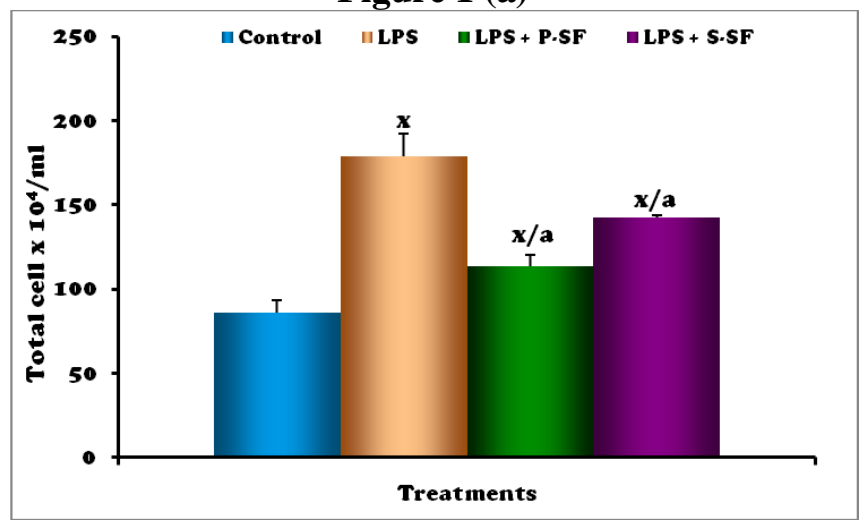

Figure 1 (b)

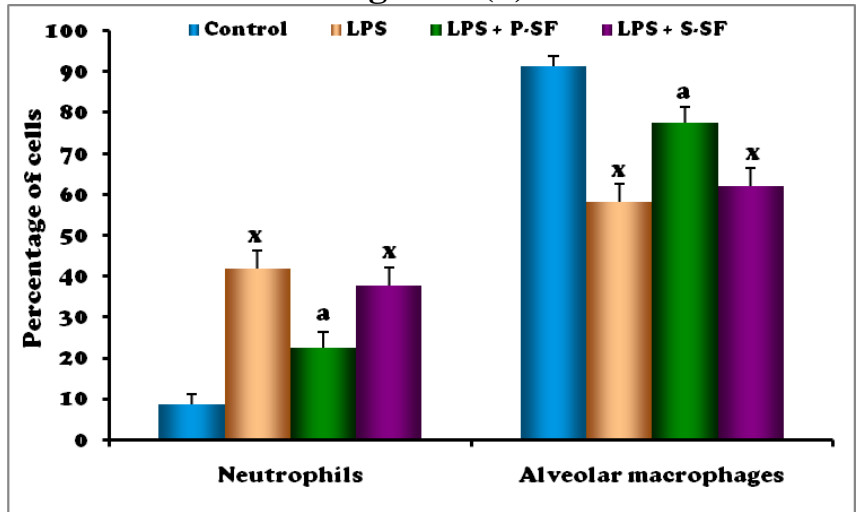

Figure 1- Inflammatory cells in BALF: (a) the number of total cells in BALF and (b) percentage of neutrophils and alveolar macrophages in BALF. Bars indicate mean \pm S.D. of five animals. ${ }^{\mathrm{x}} \mathrm{p}<0.001 \mathrm{vs}$ control rats and ${ }^{\mathrm{a}} \mathrm{p}<0.001$ vs LPS rats.

\section{Results}

\subsection{Analysis of the inflammatory cells in BALF}

BALF was used to assay the neutrophil count as an independent assessment of alveolar inflammation. A large number of neutrophils migrated into the alveolar spaces $72 \mathrm{~h}$ after LPS instillation. In the present results, the numbers of total cells and neutrophils were significantly increased in LPS treated rats as compared to the control rats. Exogenous surfactant administration decreased the numbers of total cells and neutrophils in rats stimulated with LPS. Cell count and differential results are summarized in Figure 1. Total cells equaled $86 \times 10^{4}$ cells $/ \mathrm{ml}$ out of which $91.41 \%$ were alveolar macrophages and $8.58 \%$ were neutrophils in the control group. With LPS exposure a marked increase in the total cells occurred, $178.5 \times 10^{4}$ cells $/ \mathrm{ml}, \mathrm{p}<0.001$ principally due to an influx of the neutrophils (41.84\% neutrophils and $58.15 \%$ alveolar macrophages). A decrease in total cell count and profile had changed again with both exogenous surfactant, in $\mathrm{P}-\mathrm{SF}$ (total cell count is $113.5 \times 10^{4}$ cells $/ \mathrm{ml}$, $22.52 \%$ neutrophils, $77.47 \%$ alveolar macrophages) and in S-SF group (total cell count is $142.5 \times 10^{4}$ cells $/ \mathrm{ml}, 37.81 \%$ neutrophils, $62.18 \%$ alveolar macrophages).

\subsection{Pulmonary edema assessment}

Intratracheal injection of endotoxin into the rats increased wet/dry weight ratio from $5.23 \pm 0.053$ to $6.04 \pm 0.013$ while with P-SF the W/D weight ratio was reduced to $5.493 \pm 0.051$ and to $5.671 \pm$ 0.060 with S-SF (Figure 2).

\subsection{Neutrophil influx}

MPO activity in lung homogenates was measured to quantify the relative neutrophil accumulation in the lung. As shown in figure 3 MPO activity was not detected (negligible) in lung homogenates from control rats $(0.0225 \pm$ $0.006 \mathrm{U} / \mathrm{g})$ but MPO activity significantly increased to $1.308 \pm 0.47 \mathrm{U} / \mathrm{g}$ at $72 \mathrm{~h}$ after LPS instillation whereas with surfactant treatments the MPO activity was lowered to $0.284 \pm 0.025 \mathrm{U} / \mathrm{g}$ and $0.542 \pm 0.141 \mathrm{U} / \mathrm{g}$ with $\mathrm{P}-\mathrm{SF}$ and $\mathrm{S}-\mathrm{SF}$, respectively.

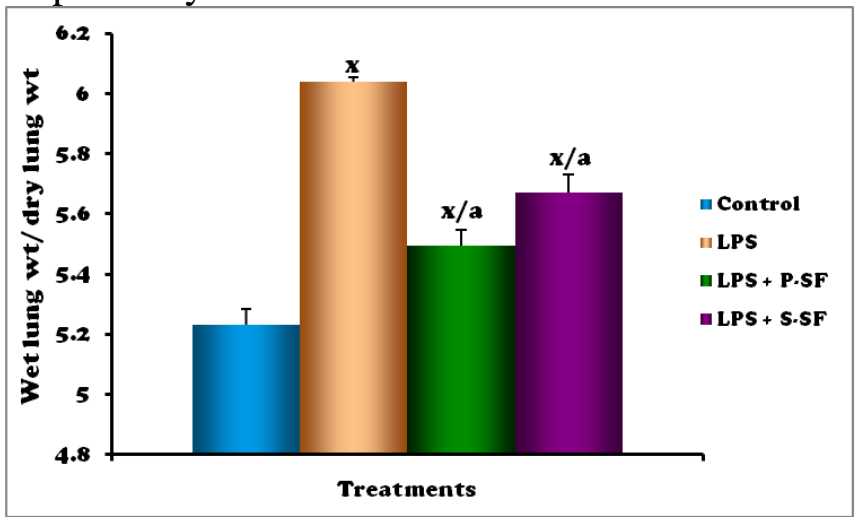


Figure 2- Ratio of wet lung weight and dry lung weight calculated as a measure of pulmonary edema formation. Bars indicate mean \pm S.D. of five animals. ${ }^{\mathrm{x}} \mathrm{p}<0.001$ vs control rats and ${ }^{\mathrm{a}} \mathrm{p}<0.001$ vs LPS rats.

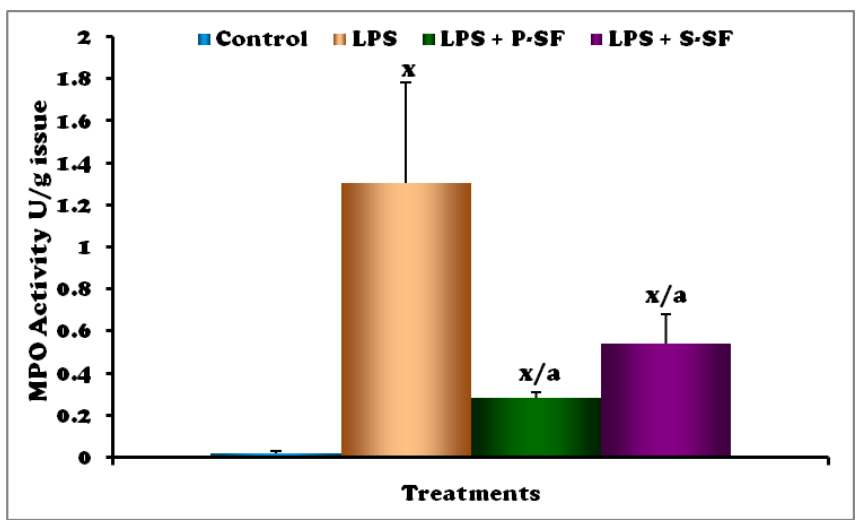

Figure 3- Mesurement of activity of myleoperoxidase (MPO). Bars indicate mean \pm S.D. of five animals. ${ }^{x} p$ $<0.001$ vs control rats and ${ }^{\mathrm{a}} \mathrm{p}<0.001$ vs LPS rats.

\subsection{MDA levels}

Similarly, LPS induced significant increase in MDA levels $(26.91 \pm 0.88, \mathrm{p}<0.001)$ in lung tissue compared to that in saline solution control group $(17.03 \pm 1.82)$. Treatment with surfactant significantly attenuated the increase in MDA level in P-SF $(22.1 \pm 1.56)$ and $\mathrm{S}-\mathrm{SF}(22.53 \pm 1.22)$ group lung tissues (Figure 4 ).

\subsection{Cytokines level in BALF}

In control animals, the IL- $1 \beta$ concentration of $659 \mathrm{pg} / \mathrm{ml}$ was measured in the respiratory compartment. Upon lipopolysaccharide stimulation, it increased to $928.6 \mathrm{pg} / \mathrm{ml}(\mathrm{p}<0.001)$ and was attenuated by intratracheally applied P-SF to $681 \mathrm{pg} / \mathrm{ml}(\mathrm{p}<0.001)$. S-SF reduced IL-1 $\beta$ to $686 \mathrm{pg} / \mathrm{ml}(\mathrm{p}<0.001)$ (Figure 5).

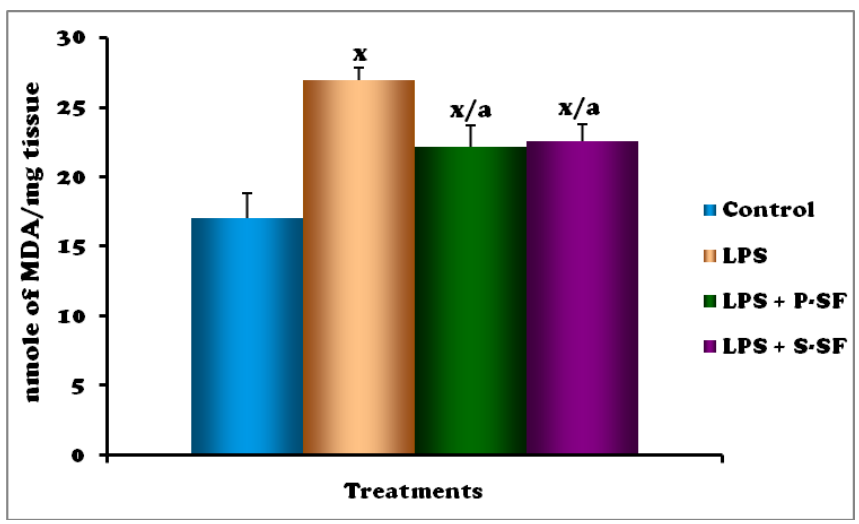

Figure 4- Malondialdehyde (MDA) level measurement in lung homogenates. Bars indicate mean \pm S.D. of five animals. ${ }^{\mathrm{x}} \mathrm{p}<0.001 \mathrm{vs}$ control rats and ${ }^{\mathrm{a}} \mathrm{p}<0.001$ vs LPS rats.

TNF- $\alpha$ concentration increased from $383.5 \mathrm{pg} / \mathrm{ml}$ in control animals to $616.3 \mathrm{pg} / \mathrm{ml}$ in endotoxin injured animals $(\mathrm{p}<0.001)$. In the presence of intratracheally applied exogenous surfactant, TNF- $\alpha$ level were reduced to $484.6 \mathrm{pg} / \mathrm{ml}$ and $554 \mathrm{pg} / \mathrm{ml}$ by P-SF and S-SF, respectively.

IFN- $\gamma$ levels were increased from $357.0 \mathrm{pg} / \mathrm{ml}$ in control rats to $544.3 \mathrm{pg} / \mathrm{ml}$ in LPS treated groups $(\mathrm{p}<0.001)$. With instillation of surfactant the IFN- $\gamma$ levels were $484.5 \mathrm{pg} / \mathrm{ml}$ in P-SF and $492.0 \mathrm{pg} / \mathrm{ml}(\mathrm{p}<0.001)$ in $\mathrm{S}-\mathrm{SF}$ group $(\mathrm{p}<0.001)$.

$\mathrm{MCP}-1$ plays a crucial role in neutrophil recruitment in the endotoxin-induced lung injury. In control lungs, a MCP-1 concentration of $1238.5 \mathrm{pg} / \mathrm{ml}$ was measured, which increased to $1760.5 \mathrm{pg} / \mathrm{ml}$ in lipopolysaccharide injured lungs $(\mathrm{p}<0.001)$. In the presence of intratracheal P-SF, this increase was reduced to $1323 \mathrm{pg} / \mathrm{ml}$. S-SF instillation lowered the MCP-1 concentration to $1578 \mathrm{pg} / \mathrm{ml}$.

Endotoxin caused an increase in MIP-2 level in the BALF from $346.6 \mathrm{pg} / \mathrm{ml}$ (control animals) to $483.16 \mathrm{pg} / \mathrm{ml} \quad(\mathrm{p}<0.001) . \quad$ Surfactant was administered intratracheally and MIP-2 level was decreased to $469.5 \mathrm{pg} / \mathrm{ml}$ and $475.5 \mathrm{pg} / \mathrm{ml}$ with PSF and S-SF, respectively $(\mathrm{p}<0.001)$.

\subsection{LDH assay}

Compared with the control group LDH levels were found to be elevated significantly in BALF of LPS (2165.3 $\pm 71.56, \mathrm{p}<0.001)$ administered rats (Figure 6), whereas with exogenous surfactant the LDH levels were reduced to $1652.6 \pm 33.71$, $\mathrm{p}<0.001$ with P-SF and to $2022 \pm 29.6, \mathrm{p}<0.001$ with S-SF. 


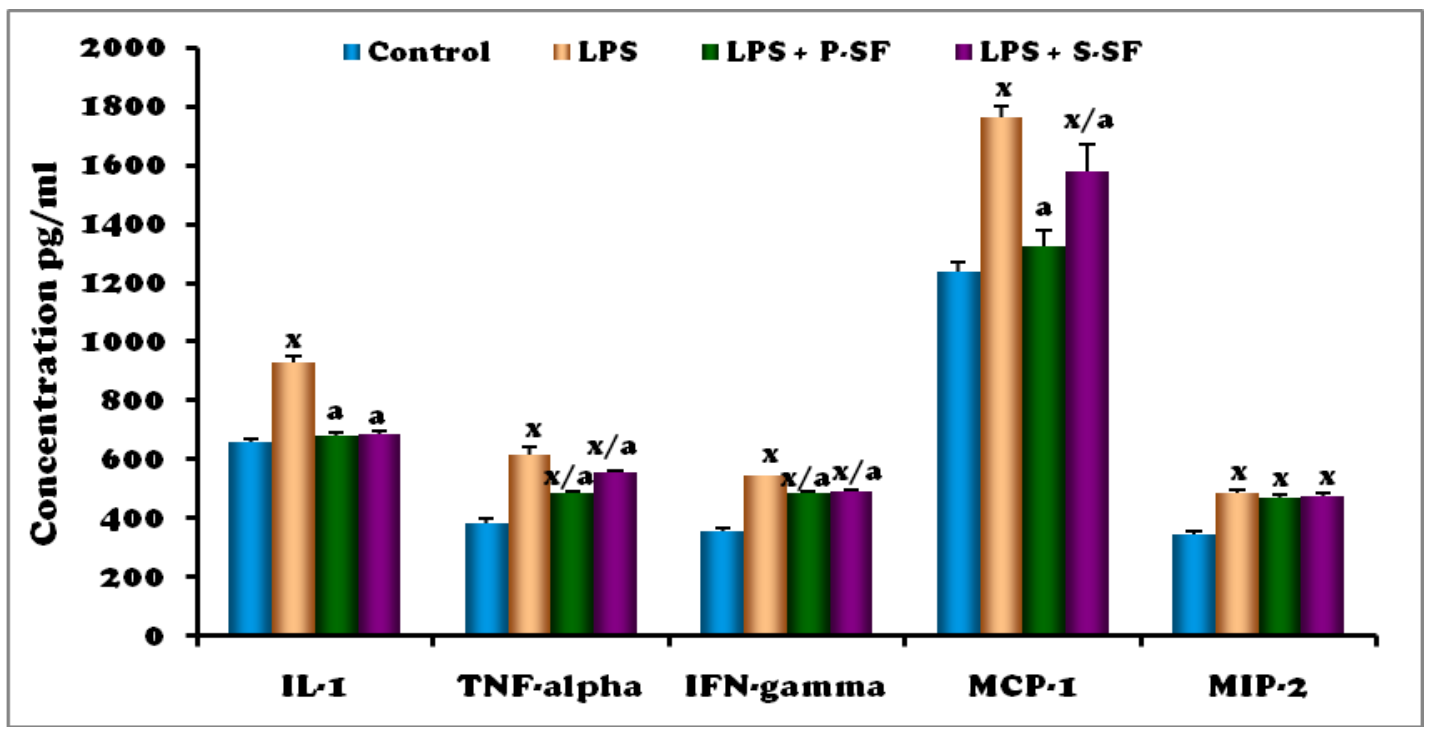

Figure 5- Measurement of pro-inflammatory cytokines in BALF. Bars indicate mean \pm S.D. of five animals. ${ }^{x} p<$ 0.001 vs control rats and ${ }^{\mathrm{a}} \mathrm{p}<0.001$ vs LPS rats.

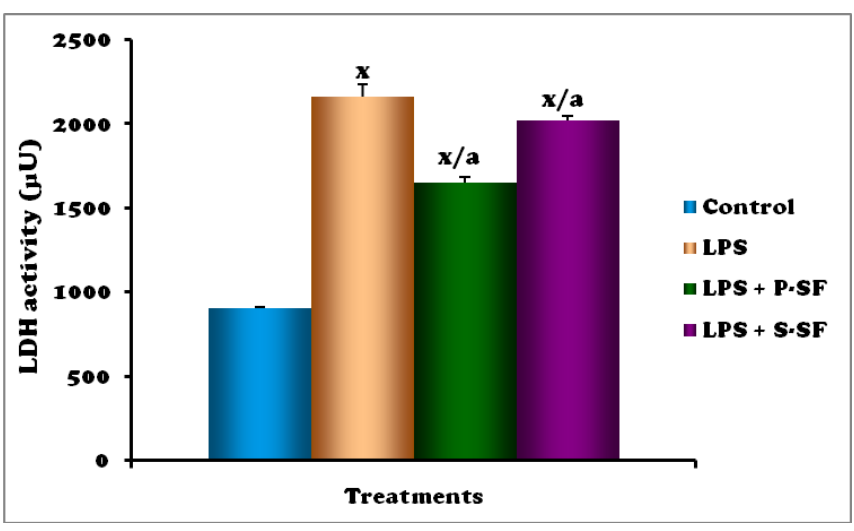

Figure 6- Measurement of lactate dehydrogenase (LDH) content in BALF. Bars indicate mean \pm S.D. of five animals. ${ }^{\mathrm{x}} \mathrm{p}<0.001$ vs control rats and ${ }^{\mathrm{a}} \mathrm{p}<0.001$ vs LPS rats.

\subsection{The caspase-1 and caspase-3 activity in lung tissues}

Accumulating evidence indicates that the activation of caspases is critical for many forms of apoptotic cell death. We examined whether the caspase activity was increased after LPS administration. Lung extracts were incubated with the tetrapeptide substrates YVAD-AMC or DEVD-AMC. YVAD-AMC is a preferred substrate for caspase-1 and DEVD-AMC is a preferred substrate for caspase-3. Figure 7 demonstrates the change of caspase- 1 and caspase3 activity in the lung tissues. The enzyme activity was assayed by measuring the extent of cleavage of the peptide substrate by the extracts. Although no change was observed in caspase-1 activity, caspase-3 activity was significantly increased in LPS treated group. The exogenous surfactant treatment suppressed caspase-3 activity in lung tissue after LPS administration (control and LPS instilled rats, $2370 \pm 355.8$ and $4348.5 \pm 382.2$, $\mathrm{p}<0.001 ;$ LPS + P-SF and LPS+S-SF, $2297.9 \pm$ 126.4 and $2841.3 \pm 238.8, \mathrm{p}<0.001$, respectively, units: $\mathrm{pmol} / \mathrm{min} / \mathrm{mgprotein}$ )

\subsection{Apoptosis by fluorescent dyes}

Figure 8 showed the dual staining of BALF cells with fluorescent dyes. In figure $8 \mathrm{a}$, yellow colored cells were apoptotic whereas green cells were live cells, and red cells depicts the necrotic cells with acridine orange-ethidium bromide. In figure $8 \mathrm{~b}$, blue cells were live cells whereas pink cells were apoptotic cells with propidium iodide and Hoechst 33342. Quantitatively, acridine orange and ethidium bromide staining revealed an increased percentage of apoptosis in LPS administered group (49\%) as compared to the control group (14\%). With exogenous surfactant the percentage was reduced to $17 \%$ and to $25 \%$ with P-SF and S-SF, respectively, as shown in figure 9. Similarly, with propidium iodide and Hoechst 33342 co-staining, 13\% apoptotic cells

(C) 2010 by NWPII. All rights reserved. 
were found in controls rats which were raised to $52 \%$ in LPS group. Further with P-SF the percentage was reduced to $16 \%$ and to $24 \%$ with $\mathrm{S}-\mathrm{SF}$.

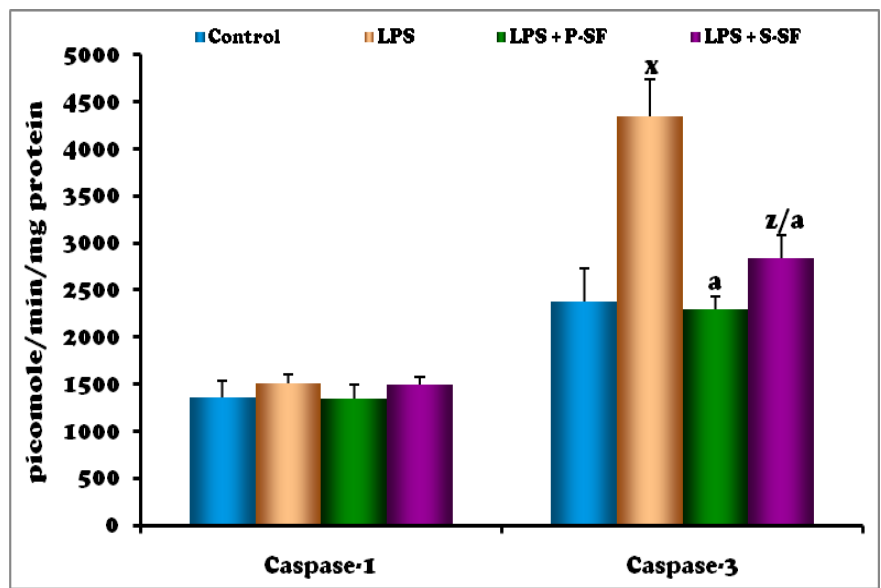

Figure 7- Change in both caspase- 1 and caspase-3 activities measured and expressed in picomoles per minute per milligram of protein. Bars indicate mean \pm S.D. of five animals. ${ }^{\mathrm{x}} \mathrm{p}<0.001,{ }^{\mathrm{z}} \mathrm{p}<0.05$ vs control rats and ${ }^{\mathrm{a}} \mathrm{p}<0.001$ vs LPS rats.

Figure 8(a)
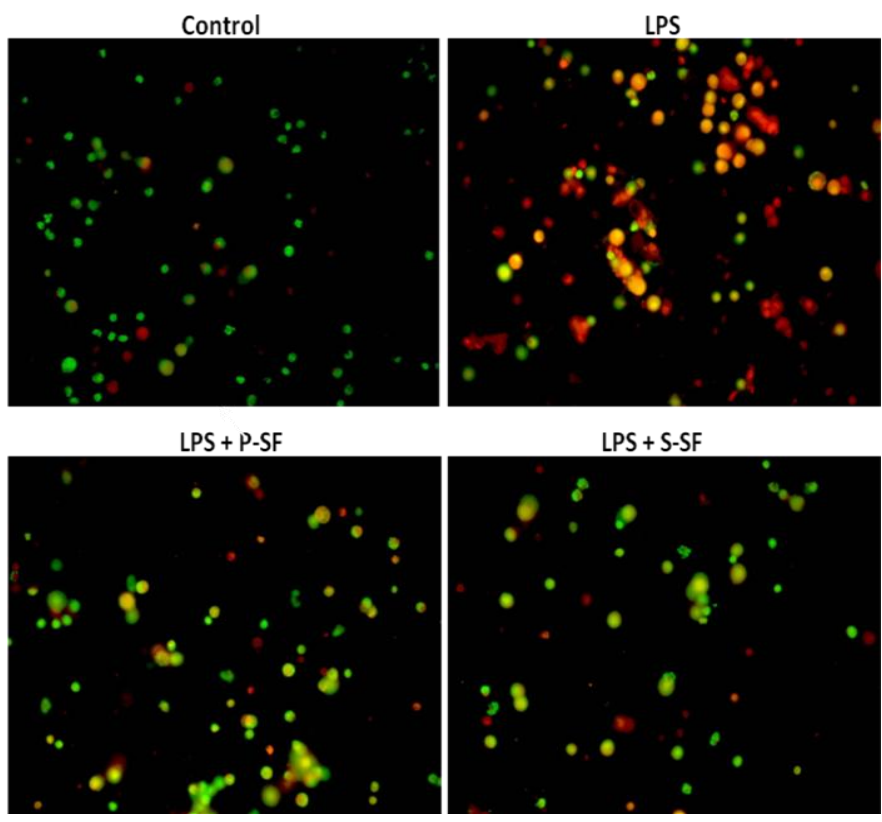

Figure 8(b)
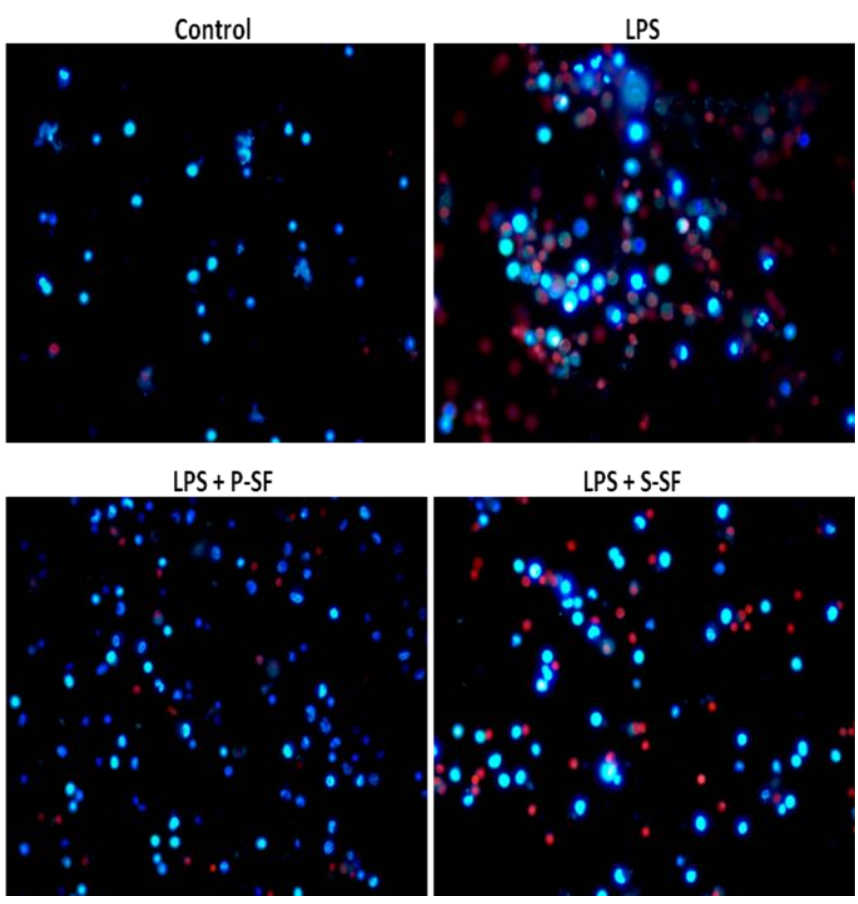

Figure 8- Photomicrograph showing apoptotic cells by staining with fluorescence dyes: (a) acridine orangeethidium bromide co-staining and (b) propidium iodide-hoechst 33342 co-staining. Total 100 cells were counted in five different slides.

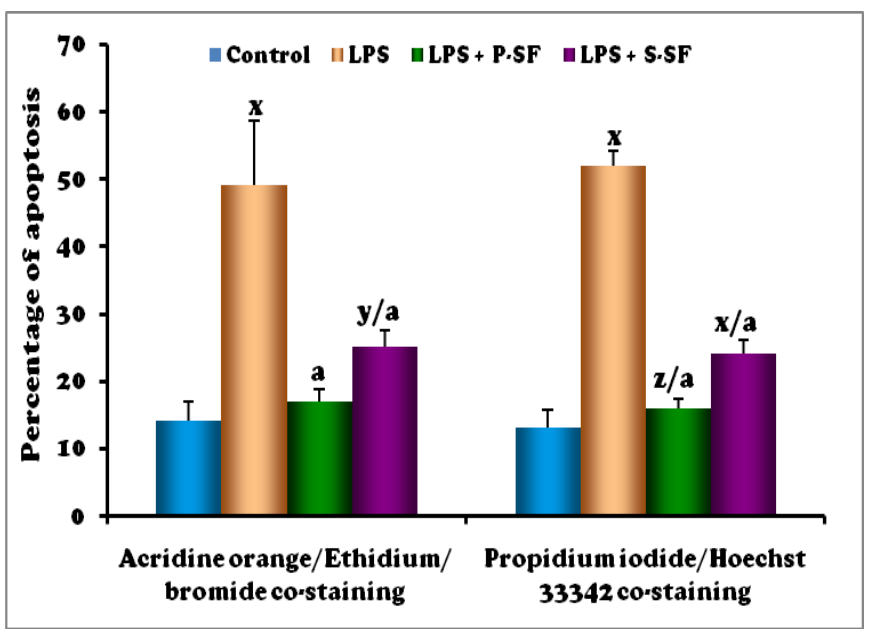

Figure 9- Quantitative analysis of the apoptotic cells as observed by fluorescence microscopy in figure 8 , percent of apoptotic cells calculated. Bars indicate mean \pm S.D. of five independent observations. ${ }^{\mathrm{x}} \mathrm{p}<$ $0.001,{ }^{\mathrm{y}} \mathrm{p}<0.01,{ }^{\mathrm{z}} \mathrm{p}<0.05$ vs control rats and ${ }^{\mathrm{a}} \mathrm{p}<$ 0.001 vs LPS rats.

\section{Discussion}


Although the intratracheal LPS instillation in murine model is a model of self-limited lung inflammation, it reproduces many features of sepsis-induced acute lung injury [29] which prompted us to carry out the present study with surfactant intubated attenuation of such injury. Several previous reports have indicated that lung injury following LPS instillation is initiated by a rapid influx of neutrophils into the airspaces followed by excessive inflammation [30]. In our study we demonstrated that intratracheal administration of endotoxin could provoke significant lung injury, which was characterized by neutrophil accumulation, pulmonary edema, cytokines and LDH levels in BALF and apoptosis of the lung associated cells. It was found that exogenous surfactant could decrease neutrophil accumulation into the lung tissue and pulmonary edema from endotoxin challenge, which might act through inhibiting the generation of proinflammatory cytokines.

The neutrophil is the primary cellular mediator in ARDS, and pulmonary neutrophil accumulation in the patients is evident in lung biopsies, postmortem specimens, and also in bronchoaveolar lavage fluid. Apoptosis of neutrophils is generally considered to be important in the resolution of inflammation [31] and apoptosis provides a way to remove neutrophils from an area of inflammation with minimal damage to the surrounding tissue. Strategies directed against either neutrophils accumulation or neutrophils function have been found to reduce sepsis induced acute lung injury [32]. The lower sequestration of neutrophils in the lung in the present study (BALF neutrophil count and tissue MPO activity) in the surfactant-LPS group suggested that neutrophil-mediated inflammation in the lung could be inhibited by surfactant. Exogenous surfactant is known to exert a variety of effects on neutrophils under experimental conditions. In quantitative terms, surfactant decreases the number of circulating neutrophils and suppresses the release of neutrophils from the bone marrow that is normally provoked by endotoxin or other stimuli [33]. In qualitative terms, surfactant decreases an in vivo migration of neutrophils [33], which could be occurring at endotoxin exposure.
TNF- $\alpha$ is regarded as the most important proinflammatory cytokine, and is released early after an inflammatory stimulus [34] while IL-1 contributes to both morbidity and mortality in conditions of "uncontrolled" inflammation [35]. Because alveolar macrophages are known to produce all three of these cytokines (TNF- $\alpha$, IL$1 \alpha$, IL-1 $\beta$ ), it is likely that macrophages are the major source of these cytokines after intratracheal instillation of LPS [36]. This early production of cytokines (IL-1 and TNF- $\alpha$ ) may be an early response by alveolar macrophages that initiates the cytokine cascade, and signals other cells in the lung to produce "distal" cytokines and other chemokines such as MCP-1 and MIP-2 that are important for signaling neutrophilic immigration.

Apoptosis or programmed cell death, plays a major role in cellular homeostasis, maintaining the delicate balance between cell proliferation and cell death [37], while recent data indicate that apoptosis plays an important role in several diseases. One of the intracellular events required for cell death is the activation of caspase, an Asp specific serine protease. A recent study has revealed two main pathways of caspase activation [38]. In the first pathway, the activation of initiator caspase- 8 is triggered by the ligation of death receptors, including Fas and tumor necrosis factor type- 1 receptors. In the second pathway, a variety of extracellular and intracellular death stimuli trigger the release of cytochrome $\mathrm{c}$ from mitochondria. Cytosolic cytochrome $\mathrm{c}$ binds to Apaf-1 (apoptotic protease activating factor-1), and Apaf-1 promotes the activation of caspase-9. Active caspase- 8 or caspase- 9 activates the effector caspase-3 [39]. The active caspase-3 mediates the cleavage of apoptotic regulators, resulting in morphological features of apoptosis and demise of the cell. We have shown here that the caspase- 3 activity and the number of apoptotic cells in the lung dramatically increased in an LPSinduced acute lung injury model. Administration of exogenous surfactant in vivo inhibited the caspase- 3 activity and prevented LPS-mediated apoptosis. In contrast to caspase-3, no increase in caspase- 1 activity was observed in the lung tissue of LPS-administered rat. An increase of caspase-3 activity without any change of caspase-1 activity has also been observed in LPS-stimulated liver 
tissues in D-galactosamine sensitized mice [40]. Caspase- 1 is considered not to be important in apoptotic processes but to be the key factor in generating the bioactive form of the proinflammatory cytokine IL-1 $\beta$ from its biologically inactive precursor [41]. Although caspase-1 activity was not increased in lung tissues, IL-1 $\beta$ concentration in the BALF was increased after LPS administration.

Intratracheal instillation of LPS induces the production of inflammatory cytokines that contribute to the pathogenesis of lung injury. LPS stimulates the synthesis and release of proinflammatory cytokines such as IL- $1 \beta$, TNF- $\alpha$, IFN- $\gamma$, MCP-1 and MIP-2 from monocytes and macrophages. These cytokines can further activate monocytes, neutrophils and lymphocytes, initiating cellular injury and tissue damage [42, 43]. Among inflammatory cells, activated alveolar macrophages and infiltrated/activated neutrophils are believed to play a major role in releasing various kinds of inflammatory cytokines and proteinases 1[44].

In conclusion, in the present study lung dysfunction is associated with marked rise in inflammatory parameters and decrease with surfactant treatment in an animal model of endotoxin-induced ARDS. However, the benefits of exogenous surfactant and treatment strategies should be carefully evaluated against possible side effects, such as increased infection as well as the associated immunological concerns.

\section{Acknowledgement}

The present work is supported by Indian Council of Medical Research (ICMR) New Delhi, India (Ref. No. 61/5/2005).

\section{References}

1. King, R.J.; Clements, J.A. Surface active materials from dog lung: composition and physiological correlation, Am J Physiol, 1972, 223, 715-725.

2. Gross, N.K.; Barnes, E.; Narine, K.R. Recycling of surfactant in black and beige mice: pool sizes and kinetics, J Appl Physiol, 1988, 64, 1027-1025.
3. Jobe, A.; Ikegami, M. State of the art: surfactant for the treatment of respiratory distress syndrome, Am Rev Respir Dis, 1987, 136, 1256-1275.

4. Ashbaugh, D.G.; Bigelow, D.B.; Petty, T.L.; Levine, B.E. Acute respiratory distress in adults, Lancet, 1967, 2, 319-323.

5. Lewis, J.F.; Jobe, A.H. Surfactant and the adult respiratory distress syndrome. Am Rev Respir Dis, 1993, 147, 218-233.

6. Avery, M.E.; Mead, J. Surface properties in relation to atelectasis and hyaline membrane disease, Am J Dis Child, 1959, 97, 571-573.

7. Gregory, T.J.; Longmore, W.J.; Moxley, M.A. Surfactant chemical composition and biophysical activity in acute respiratory distress syndrome, J Clin Invest, 1991, 88, 1976-1981.

8. Seeger, W.; Pison, U.; Buchhorn, T. Alterations in alveolar surfactant following severe multiple trauma. In: von Wichert, P.; Muller, B. eds. Progress in Respiration Research, vol. 25 Basic Research on Lung Surfactant. Basel, Karger, pp 215-223.

9. Gunther, A.; Meier, U.; Schmidt, R. Alteration of surfactant fatty acid profile in acute inflammatory and chronic interstitial lung disease, Am J Respir Crit Care Med, 1994, 151: A76.

10. Blumenthal, S.; Borgeat, A.; Pasch, T.; Reyes, L.; Booy, C.; Lambert, M.; Schimmer, R.C.; Schimmer, B.B. Ropivacaine decreases inflammation in experimental endotoxin induced lung injury, Anesthesiology, 2006, 104, 961-969.

11. Vernooy, J.H.J.; Dentene, M.A.; Suylen, R.J.V.; Buurman, W.A.; Wouters, E.F.M. Intratracheal instillation of lipopolysaccarhide in mice induces apoptosis in Bronchial Epithelial cells, Am J Respir Cell Mol Biol, 2001, 24, 569-576.

12. Kline, J.N.; Cowden, J.D.; Hunningshake, G.W.; Schutte, B.C.; Watt, J.L.; Wohlford Lenane, C.L.; Powers, L.S.; Jones, M.P.; Schwartz, D.A. Variable airway responsiveness to inhaled lipopolysaccharide, Am J Respir Crit Care Med, 1999, 160, $297-$ 303. 
13. Rylander, R.; Hanglind, P.; Lundholm, M. Endotoxin in cotton dust and respiratory function decrement among cotton workers in an experiment cardroom, Am Rev Respir Dis, 1985, 131, 209-213.

14. Hasday, J.D.; Bascom, R.; Costa, J.J.; Fitzgerald, T.; Dubin, W. Bacterial endotoxin is an active component of cigarette smoke, Chest, 1999, 115, 829-835.

15. Wagner, J.G.; Roth, R.A. Neutrophil migration during endotoxemia, J Leukoc Biol, 1999, 66, 10-24.

16. McDonald, R.J.; Usachencko, J. Neutrophils injure bronchial epithelium after ozone exposure, Inflammation, 1999, 23, 63-73.

17. Paine, R.; Rolfe, M.W.; Standford, T.J.; Burdick, M.D.; Rollins, B.J.; Strieter, R.M. MCP-1 expression by rat type-II alveolar epithelial cells in primary culture, $J$ Immunol, 1993, 150, 4561-4570.

18. Bingisser, R.; Stey, C.; Weller, M.; Groscurth, P.; Russi, E.; Frei, K. Apoptosis in human alveolar macrophages is induced by endotoxin and is modulated by cytokines, Am J Repir Cell Mol Biol, 1996, 15, 64-70.

19. Malloy, J.L.; Wright, J.R. In vivo clearance of surfactant lipids during acute pulmonary inflammation, Resp Res, 2004, 5, 1-9.

20. Suzuki, Y.; Nakai, E-ichi.; Ohkawa, K-ichi. Experimental studies on the pulmonary surfactant. Reconstitution of surface active material, J Lipid Res, 1982, 23, 53-61.

21. Raczka, E.; Kukowska-Latallo, J.F.; Rymaszewski, M.; Chen, C.; Baker, J.R. Jr. The effect of synthetic surfactant exosurf on gene transfer in mouse lung in vivo, Gene Ther, 1998, 5, 1333-1339.

22. Chabot, S.; Salez, L.; Francis, X. McCormack.; Touqui, L.; Chignard, M. Surfactant protein A inhibits lipopolysaccharide-induced in vivo production of interleukin-10 by mononuclear phagocytes during lung inflammation, Am J Respir Cell Mol Biol, 2003, 28, 347-353.

23. Zhou, Z.H.; Sun, B.; Lin, K.; Zhu, L. Prevention of rabbit acute lung injury by surfactant, inhaled nitric oxide and pressure support ventilation, Am J Respir Crit Care Med, 2000, 161, 581-588.
24. Gong, X.; Guo, C.; Huang, S.; Sun, B. Inhaled nitric oxide alleviates hyperoxia suppressed phosphatidylcholine synthesis in endotoxin-induced injury in mature rat lungs, Respiratory Research, 2006, 7(5), 1-14.

25. Chu, S.; Perng, W.; Hung, C.; Chang, D.; Lin, S.; Huang, K. Effects of various body temperatures after lipopolysaccharide-induced lung injury in rats, Chest, 2005, 128(1), 327336.

26. Kaur, J.; Sanyal, S.N. Oxidative stress and stress-signaling in chemoprevention of early colon cancer by diclofenac, Am J Biomed Sci, 2010, 2(1), 63-78.

27. Baker , A.J.; Mooney, A.; Hughes, J.; Lombardi, D.; Johnson, R.J.; Savill, J. Mesengial cell apoptosis: The major mechanism for resolution of glomerular hypercellularity in experimental mesengial proliferative nephritis, J Clin Invest, 1994, 94, 2105-2116.

28. Yuan, Y.; Zhi-Qiang, G.E.; Jing-Chuan, L. Differentiation of apoptotic and necrotic cells in suspension cultures of Taxus cuspidate by the combined use of fluorescent dying and histochemical staining methods, Biotechnol Lett, 2002, 24, 71-76.

29. Frevert, C.W.; Huang, S.; Danaee, H.; Paulauskis, J.D.; Kobzik, L. Functional characterization of the rat chemokine $\mathrm{KC}$ and its importance in neutrophil recruitment in a rat model of pulmonary inflammation, $J$ Immunol, 1995, 154, 335-344.

30. Sibille, Y.; Reynolds, H.Y. Macrophages and polymorphonuclear neutrophils in lung defense and injury, Am Rev Respir Dis, 1990, 141, 471-501.

31. Savill, J. Apoptosis in resolution of inflammation, J Leukoc Biol, 1997, 61, 375380.

32. Pulido, E.J.; Shames, B.D., Pennica, D.; O'Leary, R.M.; Bensard, D.D.; Cain, B.S. Cardiotrophin-1 attenuates endotoxin-induced acute lung injury, J Surg Res, 1999, 84, 240246.

33. Wright, J.R. Immunomodulatory functions of surfactant, Physiol Rev, 1997, 77, 931-962.

34. Hesse, D.G.; Tracey, K.J.; Fong, Y.; Manogue, K.R.; Palladino, M.A.; Cerami, A. Cytokine 
appearence in human endotoxemia and primate bacteremia, Surg Gynecol Obstet, 1988, 166, 147-153.

35. Damas, P.; Ledoux, D.; Nys, M.; Vrindts, Y.; Groote, D.; Franchimont, P. Cytokine serum level during severe sepsis in human: IL-6 as a marker of severity, Ann Surg, 1992, 215, 356362.

36. Blackwell, T.S.; Lancaster, L.H.; Blackwell, T.R.; Venkatakrishnan, A.; Christman, J.W. Differential NF- $\kappa \mathrm{B}$ activation after intratracheal endotoxin, Am J Physiol, 1999, 277, L823-L830.

37. Nagata, S. Apoptosis by death factor, Cell, 1997, 88, 355-365.

38. Thornberry, N.A.; Lazebnik, Y. Caspases enemies within, Science, 1998, 281, 13121316.

39. Kaur, J.; Sanyal, S.N. Association of PI3kinase and Wnt sinaling in non-steroidal antiinflammatory drug-induced apoptotsis in experimental colon cancer, Am J Biomed Sci, 2009, 1(4), 395-405.

40. Mignon, A.; Rouquet, N.; Fabre, M.; Martin, S.; Pages, J.C.; Dhainaut, J.P.; Kahn, A.; Briand, P.; Joulin, V. LPS challenge in Dgalactosamine-sensitized mice accounts for caspase-dependent fulminant hepatitis not for septic shock, Am J Respir Crit Care Med, 1999, 159, 1308-1315.

41. Li, P.; Allen, H.; Banerjee, S.; Franklin, S.; Herzog, L.; Johnston, C.; McDowell, J.; Paskind, M.; Rodman, L.; Salfeld, J.; Seshadri, T. Mice deficient in IL- $1 \beta$ converting enzyme are defective in production of mature IL-1 $\beta$ and resistant to endotoxic shock, Cell, 1995, 80, 401-411.

42. Svanborg, C.; Godaly, G.; Hedlund, M. Cytokine responses during mucosal infections: role in disease pathogenesis and host defence, Curr Opin Microbiol, 1999, 2, 99-105.

43. Matsukawa, A.; Yoshinaga, M. Sequential generation of cytokines during the initiative phase of inflammation, with reference to neutrophils, Inflamm Res, 1998, 47, S137S144.

44. Jacobson, J.R.; Barnard, J.W.; Grigoryev, D.N.; Ma, S.F.; Tuder, R.M.; Garcia, J.G. Simvastatin attenuates vascular leak and inflammation in murine inflammatory lung injury, Am J Physiol Lung Cell Mol Physiol, 2005, 288, L1026-L1032. 